\title{
THE POET OF THE GREAT REALITY: CZESŁAW MIŁOSZ'S READINGS OF WALT WHITMAN
}

\author{
MARTA SKWARA
}

IN THE TWO ENGLISH-LANGUAGE ARTICLES devoted to the relationship between Czesław Miłosz and Whitman, ${ }^{1}$ Miłosz has been viewed more as an American poet of European background than as a Polish poet who was an accidental resident in America. What I want to do here is to demonstrate how Miłosz, as a young Polish poet, became fascinated with Whitman's poems when he read them in Polish translations in pre-World War II Poland, and then suggest just what the poetic consequences of that early fascination were. I will also examine Miłosz as a Polish translator of Whitman's poems, a translator whose deliberate choice of texts was driven by a deep personal interest, one that is testified to by substantive comments throughout his essays. I will then indicate some affinities between Miłosz's and Whitman's poetry and look at intertextual references to Whitman found in Miłosz's writings. I will focus on the important Polish context, which, so far at least, has barely been explored in the English-speaking world.

There are three main phases of Miłosz's acquaintance with Whitman. The first encompasses Miłosz's reading of Polish translations of Whitman's poems in pre-war Poland and his recognition of the Polish fascination with Whitman. This phase is evident in "Traktat Poetycki" ["A Treatise on Poetry"], written in Warsaw in 1954-1955, and in a long poem "Po ziemi naszej" ["Throughout Our Land"], written in Berkeley in 1961. He gained a deeper insight into Whitman and his role in American and European poetry when he read him in the original English during his sojourn in Berkeley in the 1960s and the period following. The main texts reflecting this insight are Widzenia nad zatoka San Francisco [Visions from San Francisco Bay], written in Polish in 1969, in the U.S., and Ogród nauk [The Garden of Knowledge] and Nieobjęta ziemia [Unattainable Earth], both written in Polish and first published in France, in 1979 and 1984 respectively. Between the 1960s and the mid-1980s, most of Miłosz's Polish translations of Whitman were published-in France, in the U.S., and, finally, in Poland. ${ }^{2}$ The final phase (1990s 
to Miłosz's death in 2004), which is perhaps the least creative but the one most pregnant with commentaries formulated in different essays and his anthology of world poetry, ${ }^{3}$ establishes Miłosz's final view of Whitman, who, at the end, is turned into what I would call, based on Miłosz's many remarks, "the poet of the great reality." Certainly, there are no rigid boundaries between these phases, and sometimes ideas and opinions jotted down at different times and in different countries and languages seem to merge or even contradict one another. But in trying to grasp the complex totality of Miłosz's interest in Whitman, it is necessary to put that evolving interest into a chronological, linguistic, and even geographical perspective. In this way, Miłosz's shifts between cultures, languages, and traditions become easier to grasp.

According to Miłosz, his initial encounter with Whitman took place through Alfred Tom's Polish translations of some poems from Leaves of Grass. Asked by Ewa Czarnecka about his interest in Whitman, Miłosz said: "I've written about that in The Garden of Knowledge [Ogród nauk ${ }^{4}$. ... [O]ne man is responsible for my interest in Whitman-Alfred Tom, who translated a number of his poems, and, I think, very well. I read them in a volume of Lam's encyclopedia. . . . I was very taken by Tom's translations. I was a young man then; later I had a desire to read Whitman in original." 5

"Lam's encyclopedia" in fact appeared in two editions. The first one, under the title Panteon Wielkich Twórców Poezji i Prozy. Antologia literatury Powszechnej, was published in Warsaw in 1932; the second one, Wielka Literatura Powszechna, was published a year later. Both editions, however, include the same set of translations of Whitman's poems. ${ }^{6}$ Alfred Tom was not the only Polish translator of Whitman, yet for some reason he became "the only one" for Miłosz; it is worth noting that Miłosz, for his own translations, later reverted to the two poems translated by Alfred Tom. ${ }^{7}$ Miłosz's infatuation with Tom's translations, mentioned several times in his essays, ${ }^{8}$ has a surprising poetical outcome, one that English or the American readers will miss. Consider the English translation of Miłosz's 1961 poem, Po ziemi naszej, which reads:

\footnotetext{
When I pass'd through a populous city

(as Walt Whitman says, in the Polish version)

when I pass'd through a populous city,

for instance near San Francisco harbor, counting gulls,

I thought that between men, women, and children there is

something, neither happiness nor unhappiness ${ }^{9}$
}

Yet in the Polish original the three first lines read: 
Kiedy przechodziłem miastem ludnym

(jak mówi Walt Whitman w przekładzie Alfreda Toma), [(as Walt Whitman says in Alfred Tom's translation),] kiedy przechodziłem miastem ludnym, . . .

Further, there is another version of the poem in which the name of the translator reads "Konrad Tom"10 (actually the brother of Alfred and a well-known author of cabaret texts). Neither of the Tom brothers, however, ever translated Whitman's “Once I Pass'd through a Populous City." Miłosz's mistake is easy to understand when we remember that he was cut off from books in Polish and quoted the line from memory. In fact Miłosz "repeated" the line from another translation with which he was familiar, ${ }^{11}$ that of Stefan Napierski. Miłosz changes Napierski's first word from the somewhat artificial and pretentious "niegdys" ("in bygone days") into the more natural "kiedy" ("when"), which was in tune with Miłosz's frequent emphasis on the value of natural speech in poetry. I will return to Napierski later, because I believe his impact on Miłosz (as a translator of Whitman) was greater than Miłosz himself was ready to admit.

What seems, then, to be one of the most obvious cases of intertextuality - a quotation - becomes much more tricky than one might expect, and the interpretation of the poem will vary depending on the language version one reads. In the Polish, a translator-a particular person introduced with his full name-is a much more important figure: it is he who is the creator of the sounds and meanings that fall deeply into the poet's memory, and his "home" memory is intimately connected with his native language and native "realm" (to use Miłosz's own words). ${ }^{12}$ In the English, an impersonalized "Polish version" fails to evoke such meanings, especially since "the Polish version" is rendered in English, as if Whitman "spoke" in Polish simply by using a slightly different English wording (in fact, only the first word is changed: compared to the original English version, the "once" that "Whitman says" becomes "when" in "the Polish version").

The phrase "Kiedy przechodziłem miastem ludnym" has a unique value to Polish ears, sounding both natural and poetical thanks to the ten-syllable, regularly (but not artificially) stressed line, ${ }^{13}$ which follows a natural rhythm of speech, and the deliberate word choice. The first three words might form the beginning of an ordinary sentence but the last one might suggest something out of the ordinary: while cities are usually "tłoczne" (crowded), this city is not even full of people ("pełne ludzi") or populated ("zaludnione") but "ludne," a word which rings as slightly archaic or legendary. As it would be hard to find a better Polish rendition of Whitman's "Once I pass'd through a populous city,"14 it is little wonder that Miłosz wished to repeat it after the Polish translation 
he must have remembered. Miłosz's poem itself evokes a situation of being a stranger in the world. The voice of "the foreign poet" is incorporated into the text as a familiar voice, a familiar sound, and a part of a familiar heritage: that is the main effect produced by this particular translation of the American poet done in Poland before the Second World War-that is, in a free country. Yet, in 1961, the country is no longer free, and the poet is in exile, in the homeland of another poet whom he now remembers as part of his own tradition. Thus Miłosz "re-passes" through a populous city, which in his poem happens to be San Francisco, trying to find the meaning of "something among men, children and women," something that cannot be defined, "neither happiness nor unhappiness."

Paradoxically, the whole situation evoked by the first stanza of the poem may be fully understood only by Polish readers, to whom the poet addresses his text, beginning with a quotation from an American poet, and referring to several international symbols and figures (Pascal, Mozart, Cabez), but written in Polish. The English translation, though it makes the poem more universal, deprives it of its particularity. As there is no universal language, there is also no universal communication. Miłosz was well aware of the paradox of his situation: in 1978 he described himself as "a poet who can be read only in translation and whose poems do not translate well because of many cultural-linguistic allusions in their very texture." 15 The fact that Whitman speaks in English in the Polish version seems to double the paradoxes of the cultural-linguistic allusions.

One more trace of Miłosz's early acquaintance with Whitman and Polish responses to him can be detected in his Traktat poetycki. Describing Polish poets active in the 1920s and 1930s and the reaction to their poetry among Polish readers, Miłosz wrote:

What they really wanted was a new Whitman

Who, amidst the wagoners and lumbermen,

Would make everyday life shine out like the sun.

Who would see in tongs, hammers, planes and chisels

Brilliant man running through the cosmos.

"They" initially seems to denote "the readers," but "they" are also the Polish poets ${ }^{16}$ trying to find new modes of poetical expression, especially two of them-Julian Tuwim ${ }^{17}$ and Kazimierz Wierzyński-who were enthusiastic readers of Whitman. Miłosz's opinion of Tuwim was not high: "He aspired to long poems / But his thought was conventional, used / As easily as he used assonance and rhyme/ To cover his visions, of which he grew ashamed." 18 Wierzyński was rendered more as a tragic figure, ${ }^{19}$ perhaps because the price he had to pay for "a young man's 
joy, for spring and wine," was all too well-known to Miłosz, the exile. "Spring and wine" is an allusion to Wierzyński's youthful collection of poems entitled Wiosna i wino (1919), which includes the poem Odwiedziny ["A Visit"], which portrays a poetical meeting of poets. In this poem, Wierzyński himself, Tuwim, Leopold Staff, Igor Siewierianin, and Whitman, gather around glasses of red wine, enthusiastically sing together, wander around, and talk. Miłosz's short poem from his 1955 "Album of Dreams" cycle could well be reminiscent of Wierzyński's poetical image of dancing with the poets: ${ }^{20}$

\section{Album of Dreams}

December 3

With a broad white beard and dressed in velvet,

Walt Whitman was leading dances in a country manor

owned by Swedenborg, Emanuel.

And I was there as well, drinking mead and wine.

At first we circled hand in hand

and resembled stones overgrown with mold,

set into motion. Then the invisible

orchestras played more quickly, and we were seized

by the madness of the dance, in elation.

And that dance, of harmony, of concord

was a dance of happy Hasidim.

Miłosz’s dreamlike longing for "a country manor" ("mały dworek" in Polish calls up the tradition of a peaceful and harmonious country life) and for participation in a mystical meeting with dead poets may be read as the longing for the lost presence of the native culture-evoked by the phrase which traditionally concludes Polish fairytales ("I ja tam byłem, miód i wino piłem" ["And I was there as well, drinking mead and wine"]) - as well as the longing for poetical sacredness. Not surprisingly, the old Whitman, "dressed in velvet," the one making peace with life and death (known also by Miłosz's own translation of The Last Invocation), ${ }^{21}$ leads dances in the manor estate of the great mystic Swedenborg. The Hasidim tradition and the ecstatic dance connect the poetical image with the tradition of the just (this is one of the meanings of the Hebrew Hasidim) and rejected (the Hasidims' fate). By so implying, Miłosz renders one more poetical yearning: for the mysticism of poetry that vanishes and becomes the object of sneers. Miłosz would revert to this notion throughout his whole poetic life, the last strong accent of such an attitude being $A$ Book of Luminous Things (1996), in which much space is devoted to Whitman. 
Before we look at the last phase of Miłosz's interactions with Whitman, however, we need to examine two more aspects of his beginnings as a Whitmanite. In 1945, in a Polish literary magazine entitled Przekrój, Miłosz published his first translation of Whitman, "Dirge for Two Veterans," a choice all too obvious in the post-war context, in a country in which the war took a heavy toll of lives (the Polish title "Pieśn dla poległych" ["A Song for the Fallen"] emphasizes the general appeal). Yet the way Miłosz dealt with the translation is surprising: while Whitman uses repetition only in the second stanza, Miłosz applies the same device in the first, repeating the words "promien" (sunbeam) and "księżyc" (moon) three times each (Whitman repeats "moon" four times in the second stanza, each time in a different context, which probably was too obtrusive to Miłosz's ears). Miłosz intensifies the poetical organization of the text; both "promień" and "księżyc" are repeated three times in the first three lines of the two opening stanzas, which makes the poetic form much more carefully wrought in Polish than in English. ${ }^{22}$ Miłosz's choice of words and rhythm is also more deliberate than Whitman's. While the two last lines of the fourth stanza read in English,

And every blow of the great convulsive drums,

Strikes me through and through ...,

Miłosz’s translation reads,

I to każde uderzenie konwulsyjnych wielkich bębnów

Bije we mnie i przenika mnie na wskroś [strikes (in) me and pierces me through]

The penultimate stanza reads:

O strong dead-march you please me!

O moon immense with your silvery face you soothe me!

O my soldiers twain! O my veterans passing to burial!

What I have I also give you.

Miłosz renders the above as:

Chwalę ciebie, o marszu potężny!

Ulgę sprawiasz, księżycu ogromny!

O waleczni, idący do grobu!

To, co mam, ja też wam oddaję ...,

thus regularizing the stanza with ten-syllable lines (the last one is actually only nine syllables, though Miłosz's use of "ja" ["I"], normally omitted in Polish sentences, makes it feel longer: in contrast, note the first line of the above quoted stanza which reads "chwalę", and not "ja 
chwalę" ["I praise you"], creating a much different subject/object relation than Whitman's "you please me").

This all too aesthetic first translation is especially surprising when we compare it to Miłosz's views on poetic form expressed later, to which I will return. However, the contradiction did not seem to bother Miłosz much, as he republished the translation many times without any changes. In 1948, in the literary Polish magazine Odrodzenie, Miłosz published his second translation of Whitman: the sixth section of "Song of Myself." The choice still might have been driven by the post-war situation, when the poetic vision of the death which "is different from what any one supposed, and luckier" and of "the dead" who "are alive and well somewhere" was still very much needed. The figure of "the Lord," rendered, according to a traditional Polish image, as "Pan Bóg," created a familiar reference that facilitated the Polish reception of the poem. The poem is also in tune with Miłosz's eschatological searches, which characterized his whole poetic life. What should be stressed here is that this was the first Polish translation of this section of "Song of Myself," and it sounds beautiful and natural in Polish. Here Miłosz simply echoes Whitman's language and does not wish to "correct" him (or, perhaps, Whitman's form and tone in this poem was closer to Miłosz's own sense of what poetic language should be). We can sense Miłosz's genuine admiration for Whitman's poetic imagination breathing in this translation.

Finally, in order to better understand the Polish context of these early Whitman translations, it is worth noting Miłosz's reactions to the poetry written in Poland in the early 1950s, in the times of so-called socialist realism (which in poetry came to mean "realistic" poems describing, the more accurately the better, the struggles of "real" people with "real" things, always, inevitably, leading to optimistic conclusions). The main task of a poet was to be of service to the masses. As Miłosz pointed out quite correctly, no one could define precisely which sort of "masses" this task referred to, nor what their needs were. Yet his main objection to the young Polish poets of that time was much deeper. ${ }^{23}$ In Miłosz's view, poetry should under no circumstances be constructed out of slogans and predictable realistic pictures. To create poetry, much more is needed, and in order to indicate what was missing in the poems he criticized so harshly, Miłosz used Whitman's volume, which happened to be "at hand." He "copies, translating quickly" almost the entire Section 25 of "Song of Myself," which seems to confirm his own convictions of the poetic task:

My voice goes after what my eyes cannot reach

With the twirl of my tongue I encompass worlds and volumes of worlds. 
Speech is the twin of my vision, it is unequal to measure itself,

It provokes me forever, it says sarcastically,

Walt you contain enough, why don't you let it out then?

Miłosz's rhetorical device of "opening at random" the Whitman book that happens to be near "at hand" does not disguise the sincerity of the message he finds there nor does it disguise the authority he assigns to Whitman. At the end of his article, he addresses the young Polish poets, calling them "boys": "think for a while what was expected of a human being by the great bearded men of the nineteenth century." ${ }^{4}$ We realize that this is much more than just a rhetorically effective, concluding remark when we compare it to a subsequent note, published in Unattainable Earth:

Of course literature should be edifying. Whoever, because of an exceptionally avid imagination, succumbed to the bad influence of books, cannot think otherwise. The word "edifying" is pronounced sarcastically today and that is sufficient proof that something is wrong with us. What great works of literature were not edifying? Homer perhaps? Or The Divine Comedy? Or Don Quixote? Or Leaves of Grass? ${ }^{25}$

With no ironic smile whatsoever, Miłosz counted Whitman's book among those immortal works of literature worth studying in search of standards. ${ }^{26}$ Certainly Whitman provides standards for poetry, the existence of which Miłosz's own poetic practice also affirms, and that aspect will be remarkably visible in the second, “American," phase of Miłosz's acquaintance with Whitman.

As I have shown in my analysis of the poem "Throughout Our Lands," it is sometimes impossible to separate Miłosz's Polish and American phases in his approach to Whitman, and perhaps there is no need to do so. Yet it is an undeniable fact that during his sojourn in Berkeley, in the 1960s through the early 1980s, Miłosz produced the main corpus of his translations from Whitman (though the reasons for his choices were not given until much later), as well as his own poems that are intertextually connected with Whitman's and his essays that mention Whitman and comment on his role in American poetry. This suggests that his initial interest in Whitman was expanding continuously over the years and that Miłosz constantly felt like developing his readings of the poet whom he once described as "many Whitmans," the bard "who changes in our consciousness depending on which page we open his book." 27

We can best begin our study of this phase of Miłosz's fascination with Whitman by looking at a comment from his essays collected in Visions from San Francisco Bay. Here Miłosz sheds some light on how he perceived Whitman in the late 1960s: 
The electric current of Whitman's en masse was certainly stronger in America than anywhere else, and that bard, more complicated and more cunningly circuitous than is generally thought, closed the conduits in himself that were too private and refractory and opened those favoring that great current. When the poets of Europe were cursing the cite infernale, populated like Hades with restless specters, Whitman extolled, glorified, and blessed the human element and its irrepressible onward rush. His work has suffered a defeat because, though our experience of collective life is still strong, it has now been seasoned with a bitterness which he forbade himself. The young poets turn to him, the progenitor, the father of their line, crying, "Walt Whitman, come see what's become of your prophecy, your hymn." 28

Miłosz discerned the mood of the period and saw the affinities between "Whitman's song of the open future" and Allen Ginsberg's "opaque song" of imprisonment in an evil civilization. While Whitman was the everyman of the age of hope, Ginsberg- "Whitman turned inside out"-was the everyman of the age of doubt. ${ }^{29}$

For Miłosz, though, Whitman was "more complicated and more cunningly circuitous" than most people thought. Sixty pages further on in Visions, he explains why:

A cheerful young giant, a child in the cradle strangling centaurs, with an ever more splendid future before it - that portrait of America is ultimately mythical too. And we will probably commit no great error in assuming that a country like that Walt Whitman created in Leaves of Grass never existed and that it is derived from his imagination, like the urban wilderness with an inaccessible center-Balzac's Paris. (121)

Here, Miłosz no longer reads Whitman naively, and Whitman as the constructor of a mythical America now appears (as well as the constructor of the self-Miłosz groups Whitman with Henry Miller, Hart Crane, Ezra Pound, and Ernest Hemingway as authors of a "song of myself")..$^{30}$ Later, as a translator, Miłosz was able to illuminate the problems Whitman faced as he constructed his poetical self. In the collection Nieobjęta ziemia [Unattainable Earth] (first published in France in 1984), the reader finds - between the ever changing "I" ( "O Living Always, Always Dying") and the "I" as a child playing with its name ("What Am I After All") - the most vivid example of the dangerous play on the "selves," the "I":

Aware now that amid all that blab whose echoes recoil upon me I have not once had the least idea who or what I am,

But that before all my arrogant poems the real Me stands yet untouch'd, untold, altogether unreach'd,

Withdrawn far, mocking me with mock-congratulatory signs and bows,

With peals of distant ironical laughter at every word I have written,

Pointing in silence to these songs, and then to the sand beneath.

("As I Ebb'd With the Ocean of Life") 
Surprisingly, Miłosz aborts his translation at the end of the second part of the poem, not even commenting on the remaining two parts, as if the message he wanted to pass on was completed with the words about Nature "taking advantage" of the poet who "has dared to open his mouth to sing at all." Certainly that was an especially sensitive passage for Miłosz himself, the poet and the translator who was always painfully conscious of "mock-congratulatory signs and bows."

There were also some Whitmanian creations of the self that Miłosz wished to mask rather than expose. In the same 1984 collection, the title of the poem "We Two, How Long We Were Fool'd" is translated as "My obaj," which means in Polish we two men, and all grammar forms (pronouns and inflections, which denote gender unequivocally in the Polish language) were rendered accordingly in the whole translation. In the later edition (published in Poland, in 1986), the title was changed to "My dwoje," which means we two (human beings) of different sexes (all the forms in the text were also corrected). Did Miłosz simply change his mind about the poem, perhaps finding it not so obviously homosexual, or did he initially simply follow the path of a fellow Polish translator, Stefan Napierski, who had emphasized the poem's homosexuality, and did Miłosz only later find such a reading too unequivocal? Or was the place of publication (first in France, then in Poland) a determining factor? Miłosz never commented on the issue, but I am convinced the Napierski translation was in the poet's memory and influenced his initial choice. ${ }^{31}$

Returning now to Visions from San Francisco Bay, two more of Miłosz's observations are important for our investigation. The first one deals with Whitman's role in creating an American identity and discovering the powerful meaning of en masse: ${ }^{32}$

The very core of American literature has always been the question: "Who am I?" The individual establishes his identity physically, by relating himself to objects within the reach of his hands and eyes. Through his expanding perception he extends his own identity, first spatially, to include a village, a district, a country, then temporally, into his country's past, which must be somehow accessible to him, lest he be "nowhere." Where that is not possible, substitutes are sought, ${ }^{33}$ which is what Walt Whitman did when he borrowed the French expression "en masse," and applied it to the American scene. If I am en masse, I do not set out to define myself in terms of my knight's castle, peasant's hut, or burger store, I am Everyman and I must define myself in a universal fluidity, in a human collective in motion, composed of Everymen. . . . The "I" is then seen from outside as if it were an item in a store window, which contradicts its self-contained uniqueness. I am not speaking here about dissolving into the mass, or about communion through temperature and rhythm (it is characteristic that in Europe Whitman was read as the bard of mass meetings and marches), but rather about relating oneself to other individuals who have been thrown in the same geographically shaky position I have. (207) 
This interpretation of Whitman's en masse becomes more ironic later. In Ogród nauk [The Garden of Knowledge], Miłosz presents the reader with young revolutionaries in Belgrade, who read Whitman as the bard of democracy, of the crowd, of en masse, and as the enemy of monarchs. Since Gawryło Princip, who shot Prince Ferdinand, was a Whitmanite, Miłosz ironically concludes that the American poet was responsible for the outbreak of World War I. ${ }^{34}$

But it was not Miłosz's interest in Whitman's en masse, nor was it his identification with Whitman's need of creating the self in an alien world, that finally explains Miłosz's fascination with Whitman. It was rather a shared attitude toward humanity, which another passage explains as follows:

I am, however, immersed in humanity, subject to it, each day it creates anew, with the result that my own scarcely felt essence eludes me. . . . To be alive among the living: what does science have to do with that! What is the meaning of such an inarticulate cry? However, meaning does exist, beyond the reach of all reason in the meeting of eyes, hands, in the play of pronouns, I-he, I-she, in identity and non-identity, in perpetual regeneration, in the places ready and prepared, places forever taken anew by children, the young, old women, in happiness and unhappiness, in love and hate, a fluency of becoming, a river. It is impossible not to mention the name of Walt Whitman here, but not because Walt Whitman is America. The truth contained in the ecstatic stammering "to be alive among the living" exists separate and apart from him, and even before I had read Whitman, his sense of things compelled me to search for words and was the source of all my curiosities and passions. (63-64)

This passage is crucial: here Miłosz reveals his affinities to Whitman, or rather to the Whitman-like way of thinking/feeling, and this helps solve the riddles of the strikingly similar passages we can detect in the works of these two poets. Christopher Clausen, for example, points to a passage from Miłosz's "Hymn" (1934), finding there, to the delight of the English-bound reader, "rumors of Whitman": 35

Roll on, rivers; raise your hands, cities! I, a faithful son of the black earth, shall return

to the black earth, as if my life had not been, as if not my heart, not my blood, not my duration had created words and songs but an unknown, impersonal voice, only the flapping of waves, only the choir of winds and the autumnal sway of the tall trees. 
There is no one between you and me

And to me the strength is given.

However, Clausen does not substantiate the "rumors." The Polish reader would rather point to the passage dealing with "being among the living":

Seasons come and go, men and women mate, children in half-sleep run their hands across the wall and draw lands with a finger wet with saliva.

Forms come and go, what seemed invincible crumbles.

Yet the first impression of "sameness" is dissolved by the catastrophic tone of the entire poem, which is alien to Whitman. It should be remembered that, before World War II, it was T. S. Eliot who was the most important of Miłosz's poetic masters. In a way, Miłosz might sound similar to Whitman simply because his beliefs and interests were similar, yet it is likely that "The Hymn" actually had nothing to do with Whitman (the first volume of Polish Whitman translations appeared only in 1934, when Miłosz's poem was most probably already written). In Miłosz's later poems, we find frequent plays on Whitmanian notions: in the poem "Mid-Twentieth-Century Portrait" (1945), for example, a hero who says "Democracy with a wink" and "hates the physiological pleasures of mankind" seems to be an opaque and ironical version of Whitman's poetic persona, "fleshly, sensual, eating, drinking and breeding" and giving "the sign of democracy." Still, of course, it is only a matter of interpretation whether we want to connect the poem to Whitman or not.

The real affinity, I believe, can be detected elsewhere, in the search for a new, open poetic form. In the last version of his $A B C$, Miłosz adds one important personal remark to his earlier published general notes on Whitman's undeniable role in the liberating of the poetic form in Europe ${ }^{36}$ Commenting once again on his first readings of Whitman in Polish translations, he writes: "Immediately, revelation: to be able to write as he did! I understood that it was not a matter of form, but of an act of inner freedom, and therein lay [sic] the real difficulty." ${ }^{37}$ That failed search for a new form is expressed both in Miłosz's poems and his notes on poetry. His "Ars Poetica?" (1968) reads:

I have always aspired to a more spacious form that would be free from the claims of poetry and prose and would let us understand each other without exposing the author or reader to sublime agonies. 
And he concludes: "What I am saying here is not, I agree, poetry" (241). In Unattainable Earth, Miłosz expresses it even more self-consciously:

Since my youth I have tried to capture in words a reality such as I contemplated walking the streets of a human city [my emphasis] and I have never succeeded; that is why each of my poems seems to me the token of an unaccomplished oeuvre. I learned early that language does not adhere to what we really are, that we move in a big make-believe which is maintained by books and pages of newsprint. And every one of my efforts to say something real ended the same way, by my being driven back to the enclosure of form, as if I were a sheep straying from the flock. (32)

The phrase "walking the streets of a human city" echoes Whitman's "passing through a populous city": both poets are in search of a human and poetic oeuvre, and the quest is less successful for the poet of the twentieth-century than for his nineteenth-century predecessor, which is only natural, as Clausen points out: "It would be going too far to say that Miłosz finds Whitman an altogether kindred spirit. No skeptical twentieth-century intellectual could possibly make such an affirmation." 38

Although Miłosz saw himself as the one "being driven back to the enclosure of form" (his translation of Whitman's "Dirge" may be one example), he could nonetheless formulate his visions of the poetry of the future on the very next page of Unattainable Earth:

What will the poetry of the future be, which I think of but will never know? I know it is attainable because I experienced brief moments when it almost created itself under my pen, only to disappear immediately. The rhythm of the body will be in it, heartbeat, pulse, sweating, menstrual flow, the gluiness of sperm, the squatting position at urinating, the movements of the intestines, together with the sublime needs of the spirit, and our duality will find its form in it, without renouncing one zone or the other. (33)

Little wonder, then, that Miłosz found the poet of the nineteenthcentury one of his closest allies, the poet who wrote:

I do not press my fingers across my mouth,

I keep as delicate around the bowels as around the head and heart,

Copulation is no more rank to me than death is.

I believe in the flesh and the appetites,

Seeing, hearing, feeling, are miracles, and each part and tag of me is a miracle.

Divine am I inside and out, and I make holy whatever I touch or am touch'd from, The scent of these arm-pits aroma finer than prayer,

This head more than churches, bibles, and all the creeds. ${ }^{39}$ 
The final "phase" of Miłosz's reflections upon Whitman and his poetry is concentrated on his ability to express "reality," as manifested in his introduction to $A$ Book of Luminous Things:

My proposition consists in presenting poems, whether contemporary or a thousand years old, that are, with few exceptions, short, clear, readable and, to use a compromised term, realist, that is, loyal toward reality and attempting to describe it as concisely as possible. Thus they undermine the widely held opinion that poetry is a misty domain eluding understanding. (15)

Miłosz offers another explanation of his intentions, this time specifying Whitman as his key example:

Thus, profited from my readings in several languages, I have been preparing an exceedingly capricious selection of modern poetry aimed against modern poetry's chief tendencies: against the floods of artistic metaphors and a linguistic fabric liberated from colloquial meaning. I am searching for purity of line, simplicity, and concision. As, for example, in this short poem by Walt Whitman. ${ }^{40}$

He then quotes Whitman's “The Runner." Indeed, in this selection of Miłosz's essays we find many of Whitman's poems quoted, along with commentaries putting them into the "realistic domain." The already quoted "Dirge for Two Veterans" is reprinted with a comment which indicates, quite surprisingly, one more possible meaning of en masse:

Here is the image of a funeral procession, conceived as a kind of democratic ritual of saying farewell to heroes of the community. If Whitman sometimes uses the expression "en masse" this is perhaps the essence of what he meant by that foreign term. (188)

We also find poems that render scenes of the Civil War, like "Cavalry Crossing A Ford," which is said to "resemble illustrations drawn from [a] magazine," and "By the Bivouac's Fitful Flame," which expresses poetically "a concrete moment and remembrance." "As Toilsome I Wander'd Virginia's Woods" and "A Sight in Camp in the Daybreak Gray and Dim" are quoted "because they are the most direct in invoking the dead of that war." Further, Miłosz comments on Whitman's poetic technique, which is reminiscent of "the huge canvases of the masters of Renaissance painting," and a vision of Whitman as a poet of "avid eyes."

Whitman's wish "to enclose everything in poems" becomes less important, however, than his ability to express "all-embracing love," 42 which is illustrated by a passage from "I Sing the Body Electric." 43 Thus, from the reality of things we move to the reality of feelings, and this shift is emphasized by a remark reminiscent of Miłosz's opinions on "being among the living" expressed in the 1960s in Visions from San Francisco 
$B a y^{44}$ and also expressed in Whitman's "A Noiseless Patient Spider," not translated into Polish by Miłosz until 1994. In this poem Whitman seems to touch upon the ability to express "epiphany," which Miłosz understood as "an unveiling of reality" and defined at the beginning of $A$ Book of Luminous Things in this way:

What in Greek was called epiphanea meant the appearance, the arrival, of a divinity among mortals or its recognition under a familiar shape of man or woman. Epiphany thus interrupts the everyday flow of time and enters as one privileged moment when we intuitively grasp a deeper, more essential reality hidden in things or persons. A poem-epiphany tells about one moment-event and this imposes a certain form. (3)

The poetic epiphany was fully expressed in another Whitman poem, an early manuscript fragment now named "I Am the Poet," which Miłosz explicated in his chapter entitled "The Secret of a Thing":

The strong presence of a thing described means that the poet believes in its real existence. That is the meaning of a programmatic and unfinished poem by Walt Whitman, "I am the Poet", which rehabilitates a "naive" approach and rejects philosophy's unfavorable opinion on the direct testimony of our senses. (53)

Let us conclude by quoting "I Am a Poet" and the solemn, faithful, and convincing translation of it by Miłosz. It is, I believe, the strongest evidence of the two poets' affinities as Miłosz himself saw them at the end of his poetic career. He quoted the poem in many of his late essays (both in English and in Polish versions) and emphasized that Whitman "remained faithful to this proclamation by his ceaseless astonishment at the never-exhausted abundance of phenomena." 45

Jestem poetą rzeczywistości.

Twierdzę, że ziemia nie jest echem

Ani człowiek widmem.

Ale że wszystkie rzeczy widziane są prawdziwe.

Świadectwo i białe świtanie rzeczy są równie prawdziwe.

Rozciąłem ziemię i twardy węgiel, i skały, i lite łożysko morza,

Zeszedłem tam, żeby badać długo

I przynoszę stamtąd sprawozdanie,

Dowodzę, że wszystko tam pozytywne i gęste,

I że jest takie, jak wydaje się dziecku. ${ }^{46}$

I am the poet of reality

I say the earth is not an echo

Nor man an apparition;

But that all the things seen are real,

The witness and albic dawn of things equally real

I have split the earth and the hard coal and rocks and the solid bed of 
the sea

And went down to reconnoitre there a long time,

And bring back a report,

And I understand that those are positive and dense every one

And that what they seem to the child they are

Paradoxically, the old poet found the most poignant lines among the young poet's notes, out of which the immortal Leaves of Grass would emerge. "The participation in the management of the estate of poetry, of that in his own language and also that of world poetry,"47 the estate to which Miłosz most aspired, resulted in a contribution to literature which many call "illuminating" (as the cover of $A$ Book of Luminous Things proudly informs us). Miłosz, in his evocation of admiration for both poetry and reality, was, as Ryszard Nycz has said, ${ }^{48}$ also able to re-evoke an admiration for all the too-often forgotten old poets without whom our reality would be deprived of the basic principle that Whitman expressed metaphorically:

There is no stoppage and never can be stoppage, [. . . ]

We should surely bring up again where we now stand,

And surely go as much farther, and then farther and farther. ( $L G 240$ )

It now becomes clear why the poets of "small realism" were criticized so passionately by Miłosz in the 1950s. They betrayed both reality and poetry, while Miłosz searched for the poets who were able to change reality into poetry, while betraying neither one. Whitman was one such poet, Miłosz's favorite "American," as he announced in his $A B C$.

\section{Szczecin University}

\section{NOTES}

1 Christopher Clausen, "Czeslaw Milosz: The Exile As Californian," The Literary Review (Spring 1983), 337-349; William Heyen, "Piety and Home in Whitman and Milosz," in Walt Whitman of Mickle Street, ed. Geoffrey M. Sill (Knoxville: University of Tennessee Press, 1994), 291-296. The text I present here is a revised and expanded version of my Polish article, "Whitman 'wielki realista'-Miłosza projekt portretu autorskiego," Teksty Drugie (2004, no. 4), 56-73.

2 Following is a list of Miłosz's translations of Whitman, in chronological order (I do not note numerous reprints). 1945-1954: "Pieśń dla poległych" ["Dirge for Two Veterans"], Przekrój (Poland, 1945), 30; "Song of Myself [6]-Dziecko zapytało," Odrodzenie (Poland, 1948), 12; "Olśniewający, olbrzymi, zabiłby mnie zachód słońca" ["Song of Myself," 25], Kultura (France, 1954), 1-2. 1963-1983: "Kiedy wlokłem się z trudem lasami Wirginii" ["As Toilsome I Wander'd Virginia's Woods"], "Miasto uczt" ["City of Orgies"], "Opowiedziała mi matka (Z poematu 'Śpiący')" ["The Sleepers," 6], "Noc na preriach" ["Night on the Prairies"], "Słyszałem was, uroczyście i słodko brzmiące organy" ["I Heard You Solemn-Sweet Pipes of the Organ"], Tematy 
(USA, 1963), 6; “Z Walta Whitmana" ["Wandering at Morn"], Tematy (1969), 3132; "Dzieci Adama" ["I Sing The Body Electric," 3] and others earlier published in Gucio zaczarowany (Paris: Instytut Literacki, 1965); "Iskry spod koła" ["Sparkles From the Wheel"], "Cudy" [Miracles], "Kawaleria przechodzi rzekę w bród" ["Cavalry Crossing a Ford"], "Biwak na zboczu góry" ["Bivouac on a Mountain Side"], "Do lokomotywy w zimie" ["To a Locomotive in Winter"], "Wy zbrodniarze na rozprawach w sądzie" ["You Felons on Trial in Courts"], "My obaj" ["We Two, How Long We were Fool'd"], "O, żyć zawsze i zawsze umierać" ["O Living Always, Always Dying”], "Kiedy ocean życia zabierał mnie w odpływie" ["As I Ebb'd with the Ocean of Life," 1,2], "Kim ostatecznie jestem" ["What am I After All"], "Czy nigdy na ciebie nie przyszła godzina" ["Hast Never Come to Thee an Hour"], "Ostatnia inwokacja" ["The Last Invocation"], in Nieobjęta ziemia (Paris: Instytut Literacki, 1984). 1986-1994: "Myśląc o czasie" ["To Think of Time," 6] with others published previously, in Mowa wiązana (Warszawa: Państwowy Instytut Wydawniczy, 1986); "Widziane w obozie o szarym i ciemnym świcie" ["A Sight in Camp in the Daybreak Gray and Dim"], in: Tygodnik Powszechny (Poland, 1990), 21; "Jestem poetą rzeczywistości" ["I Am the Poet"], Kultura (France 1991), 1-2; "Biegacz" ["The Runner"], "Wiejski obraz" ["A Farm Picture"], "Bezgłośny cierpliwy pająk" ["A Noiseless Patient Spider”], and others published previously, in: Wypisy z ksiagg użytecznych (Kraków: Znak, 1994).

3 A Book of Luminous Things. An International Anthology of Poetry, edited and with an introduction by Czeslaw Milosz (San Diego, New York, London: Harcourt Brace, 1996). A Polish edition with longer comments, with references to Polish literature, and with a different set of poems in some cases is Wypisy z ksiag użytecznych (Kraków: Znak, 1994, rpt. 2000).

4 Ogród nauk (Paris: Instytut Kultury, 1979, 1981; Lublin 1986, 1981; Kraków: Wydawnictwo Znak, 1998). French edition: Czeslaw Milosz, L'immoralité de l'art. Traduit du polonais par Marie Bouvard (Libraire Arthème Fayard, 1988).

5 Ewa Czarnecka and Aleksander Fiut, Conversations with Czeslaw Milosz, translated by Richard Lourie (San Diego, New York, London: Harcourt Brace Jovanovich, 1987), 217.

6 "Z Salut au Monde" [ 1, 3, 4, 13], "Z Pieśni o mnie samym" ["Song of Myself," 21], translated by Tadeusz Grzebieniowski; "Ze Śpiewu o ostrzu topora: Wielkie miasto" ["Song of the Broad Axe," 5], "Z Bicia w bębny: Przy biwakowym płomieniu" ["By the Bivouac's Fitful Flame"], "Mogiła żołnierza" ["As Toilsome I Wander'd Virginia's Woods"], "O świcie na biwaku" ["A Sight in Camp in the Daybreak Gray and Dim"], "Pojednanie" ["Reconciliation"], translated by Alfred Tom; "Z Przypisań do Źdźiebeł [!] trawy": Miłosz’s "Gdy pogrążon w milczeniu” ["As I Ponder'd in Silence"], "Niczem niestrwożon" ["Me Imperturbe"], "Przemądrzałość" ["Savantism”]. "Poeci przyszłości" ["Poets to Come"], translated by Stefan Stasiak, in Panteon Wielkich Twórców Poezji i Prozy. Antologia Literatury Powszechnej, ed. Stanisław Lam (Warszawa: Nakładem Księgarni Trzaski, Everta i Michalskiego, 1932), 2:268-272; Wielka Literatura Powszechna, ed. Stanisław Lam (Warszawa: Nakładem Księgarni Trzaski, Everta i Michalskiego, 1933), 6:268-272.

7 In the 1960s, "As Toilsome I Wander'd Virginia's Woods" and in the 1990s "A Sight in Camp at Daybreak Gray and Dim." A comparison of Tom's and Miłosz's translations deserves a separate treatment; yet the same effort to make Whitman sound natural and simple in Polish (in more modern Polish in Miłosz's version) seems to unite both translators. 
8 In Ogród nauk (see note 4), and in Miłosz's $A B C$ (which has three different Polish versions: Abecadło Miłosza [Kraków: Wydawnictwo Literackie, 1997], Inne Abecadło [Kraków: Wydawnictwo Literackie, 1998], and Czesław Miłosz, Abecadło [Kraków: Wydawnictwo Literackie, 2001]). The last one was composed of portions from the two previous ones and translated into English as Milosz's $A B C$ 's, translated by Madeline G. Levine (New York: Farrar, Strauss and Giroux, 2002).

9 All English translations of Miłosz's poems are quoted from Czesław Miłosz, New and Collected Poems (1931-2001) (New York: ECCO HarperCollins Publishers, 2001).

10 Miłosz, Poezje (Warszawa: Czytelnik, 1981), 279. This first edition of Miłosz’s poetry in People's Poland, where his poems had been doomed to oblivion for many years, was provided with a characteristic comment: "This copy is to be sold only in Poland and in other COMECON-countries. Sale in other countries including Yugoslavia is prohibited and will be prosecuted by law."

11 This provides a good opportunity to demonstrate the crucial difference between the English and the Polish versions of Miłosz's $A B C$ : while Milosz's $A B C$ 's just reads: "I first encountered Whitman in Polish translation. He was translated by Alfred Tom, Stanisław Vincenz, Stefan Napierski" (300), Abecadło Miłosza reads: "Wdzięcznie wspominam moich poprzedników, tłumaczy Whitmana. Przekłady Alfreda Toma, przeczytane w encyklopedii literatury światowej (bodaj Lama), pozostały mi w pamięci jako doskonałe. Odtąd datowało się moje zainteresowanie. W roku 1921 ukazują się Trzy poematy ( $G d y$ bzy ostatnie kwitty na dziedzińcu, $Z$ rozkołysanej bezkreśnie kolebki, Podróż do Indii) w tłumaczeniu Stanisława Vincenza, ale nie pamiętam czy ten rzadki tomik, który udało mi się znaleźć niedawno w amerykańskim antykwariacie, trafił w dwudziestoleciu do moich rąk. Pewnie znałem przekłady Tuwima. Później przyszło 75 poematów w przekładzie Stefana Napierskiego, 1936" [sic: in fact Napierski's translations were published in 1934], 250-251.

12 I refer to one of Miłosz's collections of essays, Native Realm: A Search for SelfDefinition, translated from the Polish by Catherine S. Leach (Garden City, New York: Doubleday, 1968).

13 It could be scanned as / - (/) - / - / - / -, almost like the original.

14 Another Polish poet, Stanisław Barańczak, who, like Miłosz, spent a part of his life in the U.S. as a literature professor, did make an effort to find a completely different wording, but, it seems to me, produced too long and too archaic a phrase: "Bawiłem raz przejazdem w pewnym ludnym mieście." The phrase, coined in 1997, could have been read as a new proposal for the line known mostly through Miłosz. Andrzej Szuba, a modern translator who did numerous translations of Whitman in the 1990s and 2000s, put the line into Polish as "Kiedyś przejeżdżałem przez miasto ludne," but, by repeating the "prz" sound twice, made it too sharp.

\section{Quoted in Clausen, "Czeslaw Milosz: The Exile As Californian,” 337.}

16 "They" are presented with both slightly ironic admiration and criticism, quite characteristically concerning their poetical ability to deal with "ordinary things," called later "the loyalty toward reality," a motif to which Miłosz would revert till the end of his career:

There had never been such a Pléiade!

Yet something in their speech was flawed, A flaw of harmony, as in their masters. 
The transformed choir did not much resemble The disorderly choir of ordinary things.

17 Mentioned in Abecadto Miłosza (see note 11) as a translator of Whitman. It seems highly unlikely that Miłosz knew Tuwim's translations before World War II, as Miłosz himself implied. They were published in the 1950s.

18 And perhaps "long poems" hint at Tuwim's Whitmanesque lines in his Ars Poetica (1921), an example of his poor following in Whitman's footsteps, or perhaps "long poems" is an allusion to his doctrinal poems written in People's Poland in the early 1950s, where Whitman, echoed only too obviously, was used for political purposes - for example, Whitman's salute to all the world (before World War II, Tuwim translated Salut au Monde! into Polish, probably from Russian) was changed into the salute to the great Russian "brotherly” empire in Tuwim's 1953 poem Ex Oriente. Yet Tuwim was not as bad a poet as these examples suggest; in fact, he is widely regarded as one of the best of his generation. He was a poet who was able to deal creatively with the burden of Whitman's heritage, as his poem Trawa (Grass) indicates. See my Krag transcendentalistów amerykańskich w literaturze polskiej XIX $i$ XX wieku. Dzieje recepcji, idei i powinowactw z wyboru. [The Circle of American Transcendentalists in Polish Literature of the 19th and 20th Centuries: A History of Reception, Ideas and Literary Affinities] (Szczecin: Wydawnictwo Uniwersytetu Szczecińskiego, 2004), 286-288. Agnieszka Salska shares my point of view ("Some Uses of Walt Whitman: Leaves of Grass and Polish Modernist Poets," Revue Française d'études Américaines 108 [2006], 36).

19 Not morally superior, just more proud,

That solitude among American winters.

The trace of a bird in snow, as always.

Time doesn't hurt anymore, nor help much.

A blue jay, kin to the Carpathian one,

Would peer into Wierzyński's window.

$\mathrm{Oh}$, in the end there is a price exacted

For a young man's joy, for spring and wine.

20 Even more so when we notice that the motifs of a meeting in a dream and that of a shared dance, so important in Miłosz's poem, are expressed in the third stanza of Wierzyński's poem:

O, Przyjaciele! Z dawna po kryjomu

śniłem w komnatach nocą przy kagańcu

Żeby raz wszystkich was tak mieć w domu:

Wszak myśmy siebie znali tylko w tańcu.

[O Friends! Since long secretly

I've dreamed at nights by the oil-lamp

to have you all at home once:

as we knew one another only in dance]

\section{The first lines are:}

"At the last, tenderly,

From the walls of the powerful fortess'd house,

From the clasp of the knitted locks, from the keep of the well-closed doors,

let me be wafted"

which Miłosz put into Polish as “Teraz już lekko / Spomiędzy murów potężnej fortecy, / spod straży zamków, spod opieki zatrzaśniętych drzwi / Dajmy się unieść w górę.” 
22 The last sunbeam

Lightly falls from the finish'd Sabbath,

On the pavement here, and there beyond it is looking,

Down a new-made double grave.

Lo, the moon ascending,

Up from the east the silvery moon,

Beautiful over the house-tops, ghastly, phantom moon,

Immense and silent moon

[my emphasis]

Ostatni pada promień,

Niedzieli zakończonej ostatni pada promień,

$\mathrm{Na}$ bruk słoneczny pada promień i spogląda

Na świeżo wykopany podwójny grób.

Patrz, wschodzi księżyc,

Tam na wschodzie srebrny i okrągły księżyc,

Nad dachami piękny i widmowy dziki księżyc,

Ogromny i milczący

[my emphasis]

23 It is pointless to mention the names of the five poets he objected to, as they simply are no longer remembered in Polish poetry, which proves that bad poetry is, fortunately, not an everlasting presence.

24 Miłosz, "Młodzi poeci," Kultura (France, 1954) 1-2, 194.

25 Miłosz, Unattainable Earth, trans. Miłosz and Robert Hass (New York: Ecco Press, 1986), 38.

26 The German Pathos mentioned by Walter Grünzweig in the context of German reading of Whitman has something in common with Miłosz's view. See Grünzweig, Constructing the German Walt Whitman (University of Iowa Press, 1995), 6-7.

27 Miłosz, Ogród nauk (Kraków: Wydawnictwo Literackie, 1998), 250.

28 Miłosz, Visions from San Francisco Bay, translated by Richard Lourie (New York: Farrar, Strauss, Giroux, 1982), 64.

29 Later, in Miłosz's $A B C$ 's, Ginsberg was called “[ $\mathrm{t}$ ] he most Whitmanesque among American poets ... not so much because of his open homosexuality as through the courage with which he broke with convention, often against his own will" (300).

30 It seems that Whitman's poems praising America never interested Miłosz, though they have belonged to the Polish canon of Whitman ever since 1921.

31 It is worth mentioning here that the first two Polish translations of the poem were unequivocally heterosexual ones. The second was published in 1921 in a special number of a magazine Naród, in which the circle of Skamander poets (to which Wierzyński and Tuwim belonged) presented Whitman. None of the Skamander poets detected any homosexual traces in Whitman, though for Tuwim Whitman's erotic poems meant a lot, serving as a kind of a liberating force, as his youthful article on Whitman proves ("Manifest miłości powszechnej. (Walt Whitman)" ["A Manifesto of Universal Love. (Walt Whitman)"], Pro Arte et Studio [1917], 8) . 
32 The European reading of Whitman as the leader of the masses had its Polish version, of which Miłosz was probably not aware (I refer to the propagandist pamphlet Walt Whitman, published by Antonina Sokolicz, the translator of Upton Sinclair, in Warsaw in 1921, by the trade union publishers' house (Warszawa: Biblioteczka "Świata Pracy"). It would be worth exploring to what extent the booklet was based on Russian and German patterns, besides being obviously rooted in the Polish socialdemocratic tradition of Stefan Rudnianski's interpretations (who, incidentally, studied in Germany).

33 It is surprising how these very words could have been applied to Miłosz himself as the person who spent much of his life in exile. A few lines earlier one can find the self-comparison expressed directly: "As to my homelessness, it is what makes my integration into America easier, because its inhabitants have always suffered from homelessness and uprootedness, later called alienation" (206).

34 Miłosz repeats the anecdote several times (not only in Ogród nauk but also in the three versions of $A B C$ ).

35 Clausen, "Czeslaw Milosz: The Exile As Californian," 342.

36 In one of the collections of Miłosz's essays a reader may find a note: "Already before World War I all of European poetry had experienced an American influence thanks to Walt Whitman, who almost caused a revolution in versification by discarding meter and rhyme in favor of free verse." And, later, a personal declaration: "Frost said of free verse that it is like a game of tennis without a net. I, however, am absolutely on Walt Whitman's side." See Milosz, To Begin Where I Am: Selected Essays, edited and with an introduction by Bogdana Carpenter and Madeline G. Levine (New York: Farrar, Straus and Giroux, 2001), 377, 402.

37 Miłosz's $A B C$ 's, 300.

38 Clausen, "Czeslaw Milosz: The Exile As Californian,” 342.

39 "Song of Myself," Poetry and Prose, ed. Justin Kaplan (New York: Library of America, 1996), 211. Hereafter LG.

40 Milosz, To Begin Where I Am, 380.

41 "Some parts of the gigantic oeuvre of Walt Whitman remind me of the huge canvases of the masters of Renaissance painting. If, looking at these canvases, we direct our attention to a detail, we discover a multitude of carefully painted small scenes. The same is true in Whitman: there is something like a mosaic, composed of units that are autonomous" (202).

42 "Walt Whitman had avid eyes. He wanted to see everything, to memorize everything, and to enclose it all in his poems. But he remains for us primarily a poet of great heart, of all-embracing love, which fuses its varieties into one love, erotic, but also compassionate, protective, and marveling at everything great and magnificent in man. This aspect of his poetry prompted me to place several fragments of his oeuvre in this chapter [e.g., "People among People]" (185).

43 Remarkably, this is one of the very last Whitman poems to be translated into Polish, in the 1990s by Andrzej Szuba.

44 "I end this chapter [e.g., "People among People"] with, once again, Whitman. He spins out of himself a thread, both in his personal life and in his poems, looking for a response, an understanding, for friends, readers, the perfect opposite of an artist 
who turns away from people and the world" (210).

45 Milosz, To Begin Where I Am . . ., 381. In the quoted essay the poem was introduced as follows:

"Western poetry has recently gone so far down the path of subjectivity that it has stopped acknowledging the laws of the object. It even appears to be proposing that all that exists is perception, and there is no objective world. In which case, one may say anything, for there is no control at all. But the Zen poet advises us to learn about the pine tree from the pine tree, about bamboo from the bamboo, and this is an entirely different point of view. There are poems which, following this advice, turn toward the object, even if it does not necessarily agree with the author's views. Sometimes, the same poet will have written some poems which are for, some against. All of modern poetry is torn apart by internal contradictions and temptations. In a little-known unfinished poem Walt Whitman writes:

I am the poet of reality

I say the earth is not an echo

Nor man an apparition...

('I am the poet')"

46 In the Polish version of $A$ Book of Luminous Things, Miłosz presents Whitman's poem as "little known (and not finished)." In the English version the poem becomes "programmatic" and the last two lines are quoted ["And the world is no joke, / Nor any part of it a sham"]. Whitman's poem can be found in his "Talbot Wilson" notebook; see Whitman, Notebooks and Unpublished Prose Manuscripts, ed. Edward F. Grier (New York: New York University Press, 1984), 1:69.

47 A Book of Luminous Things, xv.

48 Ryszard Nycz, Literatura jako trop rzeczywistości. Poetyka epifanii w nowoczesnej literaturze polskiej (Kraków: Universitas, 2001), 184. 